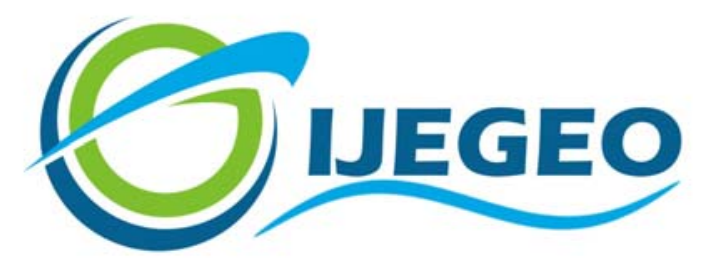

International Journal of Environment and Geoinformatics (IJEGEO) is an international, multidisciplinary, peer reviewed, open access journal.

\title{
Impact of geographical factors on coastal tourism between İğneada and Kastro Bay, Thracian Black Sea coast, Turkey
}

\author{
Gülsen Erginal
}

Editors

Prof. Dr. Cem Gazioğlu, Prof. Dr. Dursun Zafer Şeker, Prof. Dr. Ayşegül Tanık, Assoc. Prof. Dr. Şinasi Kaya

\section{Scientific Committee}

Assoc. Prof. Dr. Hasan Abdullah (BL), Assist. Prof. Dr. Alias Abdulrahman (MAL), Assist. Prof. Dr. Abdullah Aksu, (TR); Prof. Dr. Hasan Atar (TR), Prof. Dr. Lale Balas (TR), Prof. Dr. Levent Bat (TR), Assoc. Prof. Dr. Füsun Balık Şanlı (TR), Prof. Dr. Nuray Balkıs Çağlar (TR), Prof. Dr. Bülent Bayram (TR), Prof. Dr. Şükrü T. Beşiktepe (TR), Dr. Luminita BUGA (RO); Prof. Dr. Z. Selmin Burak (TR), Assoc. Prof. Dr. Gürcan Büyüksalih (TR), Dr. Jadunandan Dash (UK), Assist. Prof. Dr. Volkan Demir (TR), Assoc. Prof. Dr. Hande Demirel (TR), Assoc. Prof. Dr. Nazlı Demirel (TR), Dr. Arta Dilo (NL), Prof. Dr. A. Evren Erginal (TR), Dr. Alessandra Giorgetti (IT); Assoc. Prof. Dr. Murat Gündüz (TR), Prof. Dr. Abdulaziz Güneroğlu (TR); Assoc. Prof. Dr. Kensuke Kawamura (JAPAN), Dr. Manik H. Kalubarme (INDIA); Prof. Dr. Fatmagül Kılıç (TR), Prof. Dr. Ufuk Kocabaş (TR), Prof. Dr. Hakan Kutoğlu (TR), Prof. Dr. Nebiye Musaoğlu (TR), Prof. Dr. Erhan Mutlu (TR), Assist. Prof. Dr. Hakan Öniz (TR), Assoc. Prof. Dr. Hasan Özdemir (TR), Prof. Dr. Haluk Özener (TR); Assoc. Prof. Dr. Barış Salihoğlu (TR), Prof. Dr. Elif Sertel (TR), Prof. Dr. Murat Sezgin (TR), Prof. Dr. Nüket Sivri (TR), Assoc. Prof. Dr. Uğur Şanlı (TR), Assoc. Prof. Dr. Seyfettin Taş (TR), Assoc. Prof. Dr. İ. Noyan Yılmaz (TR), Assist. Prof. Dr. Baki Yokeş (TR), Assist. Prof. Dr. Sibel Zeki (TR), Dr. Hakan Kaya (TR). 


\title{
Impact of geographical factors on coastal tourism between İğneada and Kastro Bay, Thracian Black Sea coast, Turkey
}

\section{Gülsen Erginal}

Ardahan University, Çıldır Vocational High School, 75000 Ardahan TR

Tel : : +904782114132

E-mail : gulsenerginal@ardahan.edu.tr

\begin{abstract}
This study discusses the relationship between tourism and geomorphologic features, climatic comfort and natural vegetation cover in the coastal region from İğneada to Kastro Bay on the Black Sea. From the point of view of climatic comfort, Thermo-Hygrometric Index (THI) values indicate that May, June, September and October are favorable for coastal tourism while in the months of July and August temperatures are too hot. SSI index values indicate that comfort levels prevail for most people in June and September although the weather can be perceived by some people as cool. In July and August, when the temperatures are higher, the climate is comfortable part of the time, but it is rather hot and sticky. Despite climatic comfort conditions not being suitable for long-duration coastal tourism in the Kıyıköy-Ĭgneada area, the floristic richness of the area and presence of longose forests offer many opportunities in terms of ecotourism. There are also numerous lakes and streams presenting unique possibilities for a variety of so-far unexploited tourism activities. Geomorphologically, uncontaminated sandy beaches and coastal spits as well as sheltered bays such as Kastro Bay are among the important assets of the area in terms of coastal tourism.
\end{abstract}

Keywords: Coastal tourism, climatic comfort, Thrace, Black Sea, Turkey.

\section{Introduction}

Without excepting the inland Sea of Marmara coast in the northwest part of the country, Turkey has a long coastline of $8333 \mathrm{~km}$ that extends from the Syrian border in the southeast to the border with Georgia in the northeast. Surrounded by the Black Sea and Mediterranean to the north and south, respectively, this long coastal strip provides a wide array of opportunities for sea and yacht tourism as well as ecotourism (Y1lmaz et al., 2013), favored by suitable morphologic and climatic conditions. Nevertheless, environmental problems arising from industrial waste, lack of infrastructure, overpopulation, unplanned and rapid urbanization as well as degradation of the coastal forests and have caused serious pressure over the last 40 years, especially on the Mediterranean coastal landscape of Turkey (Akkaya et al., 1998; Atik et al., 2010; Dihkan et al., 2017). The coastal zone is very important for the national economy of Turkey and also the pressure on the coastal zone is very high. Approximately $44 \%$ of the national GDP comes from the top ten coastal cities. The elevation of these cities changes between 3 and $100 \mathrm{~m}$. The average elevation from sea level is about $50 \mathrm{~m}$. According to Kuleli (2010), a total of $7319 \mathrm{~km} 2$ is lying below the $10-\mathrm{m}$ contour line in the coastal zone of Turkey (Simav et al., 2015; Şeker et al., 2016).

Among the areas facing ecological disintegration are coastal regions where risk levels must be urgently taken into account (Burak et al., 2004; Senlier and Özturk, 2011; Gazioğlu et al., 2016). In some cases, as will be discussed herein, tourism activities may create negative consequences for tree-covered land near coastal destinations due to deforestation and forest fragmentation (Kuvan, 2012). Given the extent of the environmental impact of tourism, the Black Sea coast, has been comparatively less influenced by anthropogenic activities. This arises from both the shortness of the "sun, sand and sea" tourism season and less favorable climatic conditions, such as high rainfall and relative humidity, inadequate 
sunshine duration and low temperatures (Güçlü, 2011).

In this paper, we discuss coastal tourism along the shoreline between the town of Kiyıköy and Kastro Bay (Fig 1) in the context of tourismbased environmental problems and existing potential previously unappraised. This coastal strip, and the area behind it, holds more than half the 12,000 plant species growing in Turkey; an ecological diversity that is due to the humid climate. Having great potential for ecotourism owing to the wild forests which have not been exposed to anthropogenic damage (Demir et al., 2016) and the coastal lakes formed by temporal changes in seasonal precipitation (Özyavuz, 2011), the studied area lies between İğneada, a coastal town connected administratively to Kirklareli in the Thracian part of Turkey, and Kastro Bay (Fig 1). This coastal area and its surrounding hills and ridges, i.e. the NW-SE-trending Strandja Mountains to the west, has potential for alternative tourism activities due to its cultural and archaeological heritage in addition to unpolluted rivers running down from the highlands to the floodplains and floodplain forests (longose) and extensive sandy beaches. Thus the area has a biospherereserve potential (Gazioğlu, et al., 1997; Özyavuz, 2008; Özyavuz and Yazgan, 2010). It should be noted that this part of the Thracian Black Sea coast of Turkey possesses exceptional importance due to the entity of the Strandja Mountains, such that the whole Black Sea coastal belt from the Georgian to Bulgarian borders (about $1700 \mathrm{~km}$ ) does not provide equal tourism opportunities. On the other hand, the existing tourism potential of the area has not been appropriately appraised due to a misperception of "coastal tourism", which is due substantially to the day-trippers and visitors coming from nearby cities and the metropolis of Istanbul. We therefore discuss how the existing potential can be properly evaluated and in what way the existing perception of coastal tourism can be changed.

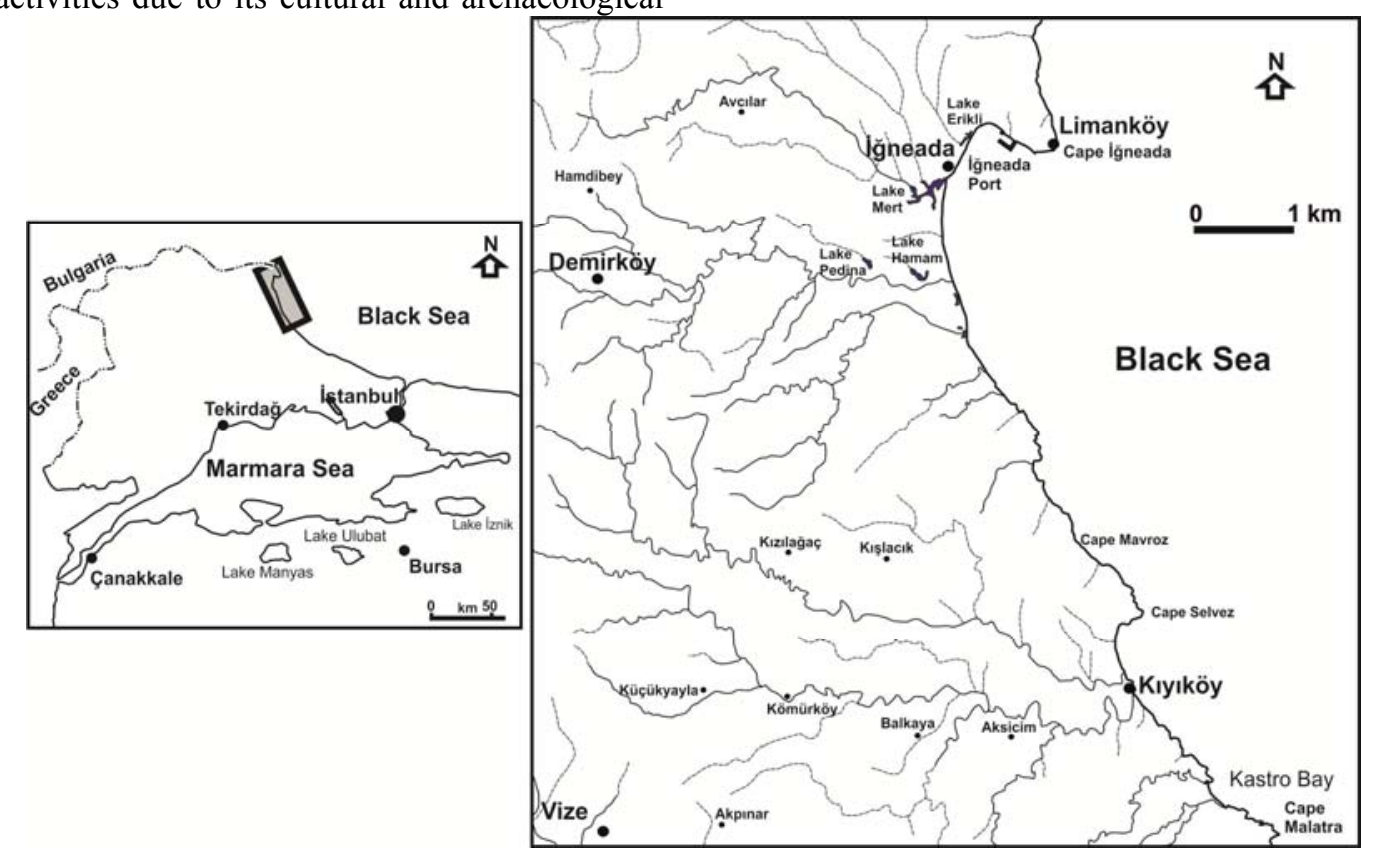

Fig. 1. Location map of study area.

\section{Study Area}

The study area comprises a 45-km stretch of shoreline on the Thracian Black Sea coast (about $800 \mathrm{~km}$ long) of Turkey extending from İğneada to Kastro Bay, which is $8 \mathrm{~km}$ southeast of Kiyıköy, a coastal town. The area is a seaward (northwestward) extending lower plateau of the Strandja Mountains, a massif composed of basement rocks such as gneiss, amphibolite and schist as well as granite and limestone (Pamir and Baykal, 1947). According to data (1975-2006) obtained from Kumköy 
Meteorology Station to the southeast, the area receives annual precipitation of $831.4 \mathrm{~mm}$. The average annual air and seawater temperature is $13.8^{\circ} \mathrm{C}$ and $14.3^{\circ} \mathrm{C}$, respectively. A five-month period from May to September corresponds to a warm period when the value of evaporation from seawater is about $600 \mathrm{~mm} / \mathrm{yr}$, significantly lower than that of the Mediterranean (about
$2000 \mathrm{~mm} / \mathrm{yr}$ ). From the climatic viewpoint, a humid-temperate Black Sea climate prevails (Türkeş, 1996; İyigun et al., 2013) and the tidal range is less than $30 \mathrm{~cm}$. Access to the area from Istanbul or Edirne near the Bulgarian border is possible via the European E80 motorway. Both towns, İğneada and Kıyıköy, lie at a distance of about $200 \mathrm{~km}$ from Istanbul.
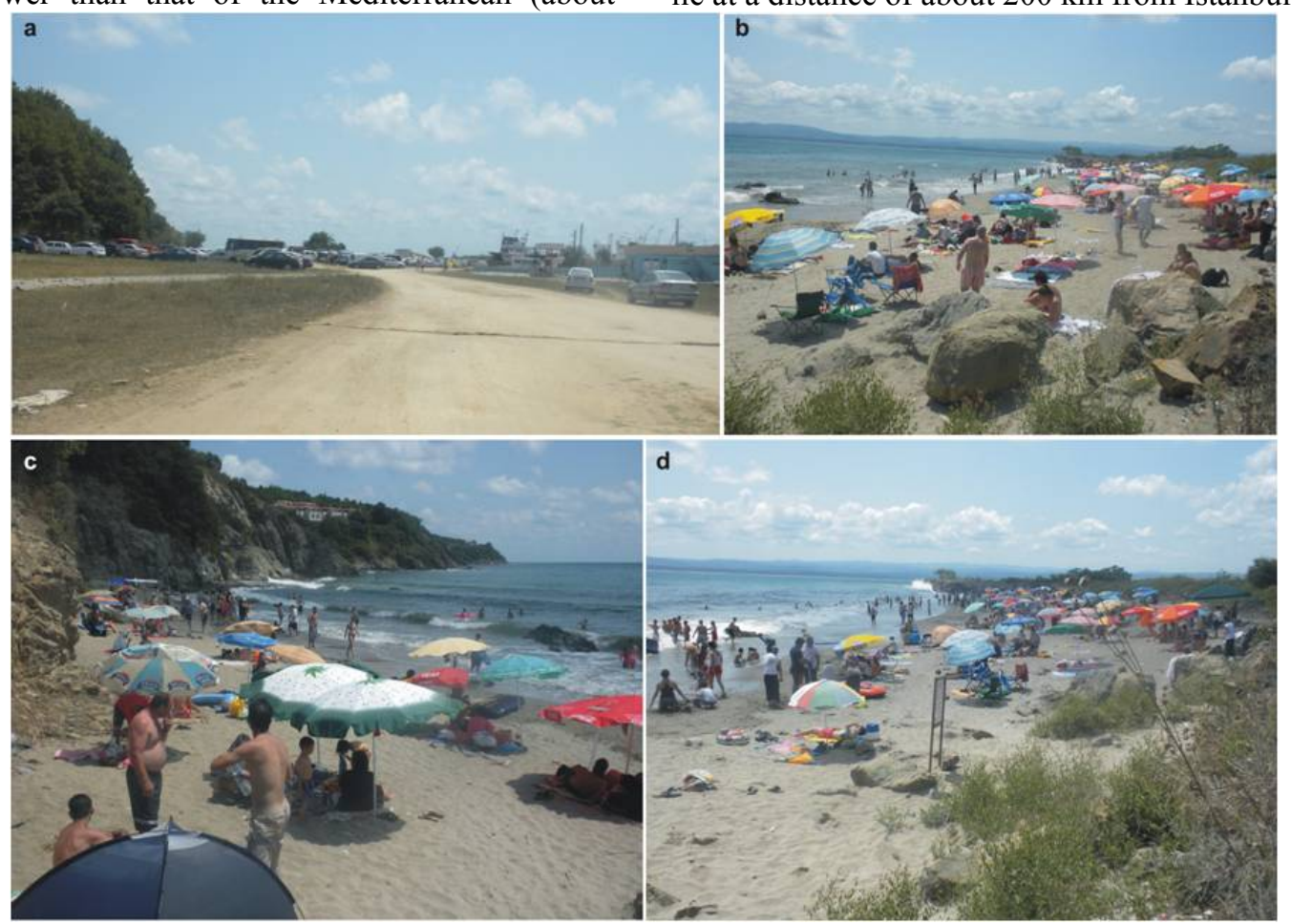

Fig. 2. . Filled area used as a car park on east coast of İğneada Port (a) and intensive use of the sandy Iğneada beach stretching in a southwest-northeast direction (b-d).

\section{Materials and Methods}

This paper is based mainly on field studies. During the spring and summer months (MayAugust) of 2010 and 2011, field observations along the coastline were performed during periods when coastal tourism was either sparse or intense. The natural potential of the area such as landforms, water resources and plant communities together with anthropogenicallyinduced land use and settlement patterns as well as population pressure on the land before and during the tourism season were examined and photographed on site. 1/50,000-scale topography maps prepared by the Turkish General Command of Mapping were used in the field studies. To determine existing land use patterns in the study area, Coordination of Information on the Environment (CORINE) land use classification by the Ministry of the
Environment and Forestry was used. In order to process spatial analysis of the data prepared in a vector format, we used Arc-GIS 9.3.1 software. The raster (grid) data is first converted using Geographic Information Systems software. The raster data produced were reclassified in accordance with the purpose of the study. Various classes of land use were identified, such as forest land, maquis and bush, meadow and pasture, dry agriculture areas, settlements, harbors, water bodies, beaches and sand dunes. From the analysis, each type of land use was calculated and the land use map was produced accordingly. To determine the relationship between tourism and climatic comfort, climatic comfort indexes were calculated. To this end, the Summer Simmer Index (SSI) and ThermoHygrometric Index (THI) were used to evaluate climatic conformity on coastal tourism in the 
study area (Pepi, 1999; Tzenkova et al., 2007). Climatic comfort calculations were performed using the 32-year (1975-2006) average of meteorological data obtained from Kumköy Meteorology Station $\left(41.15^{\circ} \mathrm{N}-29.02^{\circ} \mathrm{D}\right)$, the nearest coastal station to the study area.

\section{Results and Discussion \\ Coastal tourism around İğneada}

The coastal zone from Limanköy to Kastro Bay extends in a northwest-southeastly direction parallel to the Black Sea coast and is restricted to the west by the Strandja Mountains. This area forms part of the northwestern Thracian Black Sea coast of Turkey. The Limanköy settlement is located on the southeastern tip of a low plateau.

Tourism on the Limanköy coast is developing rapidly today. Second homes occupy space around the settlement of Limanköy. These summer residences have mostly been built on the low ridge behind İgneada Harbor. Second homes have also been constructed behind the French-made lighthouse to the east of Limankoy (Morgül, 2014). Although these houses were built on a plateau (Kurter, 1964), access to the sea is provided via narrow pathways down through small stream beds.

The surroundings of Cape Limanköy are composed entirely of high coastal cliffs with the exception of the fine sandy Iğneada beach that stretches in a southwest-northeast direction. This 150-meter long beach is a coastal sand fill area lying to the east of Iğneada Port. The area behind this man-made beach is used as a parking area for daily visitors. The beach is crowded throughout the tourism season due to heavy demand (Fig 2).

To the south of Limanköy, two lagoons, Lake Erikli in the north and Lake Mert in the south, form important natural environments for tourism. Lake Erikli is a narrow and long lagoon extending to the shoreline (southwestnortheast) at the mouth of Efendi Stream, which is dissected between undulating ridges at an altitude of 50-150 m (Fig 3a). The long axis in the northwest-southeast direction of the lagoon is $1 \mathrm{~km}$ long and the broadest part is 100 meters in width.
West of the lagoon there is a reed-swamp with a maximum width of $700 \mathrm{~m}$. This swamp is limited by the alluvial plain covered with longose (water-covered) forest to the west (Fig 3b). 200 meters behind the shoreline, Lake Erikli occupies part of an alluvial plain covered with submerged forests and swamps. The Lake Mert lagoon south of İgneada also occupies the lower part of an alluvial plain, as with Lake Erikli (Fig 4). It lies close to the shoreline in a southwest-northeast direction. The western part of the lake is swampy, and is $2.5 \mathrm{~km}$ wide from north to south and $2 \mathrm{~km}$ wide in an east-west direction. The longose forest, which limits the swamp from the west, occupies a large area of the alluvial plain, which has gradually narrowed to the west. On the other hand, different data have been suggested about the surface area of the longose forests (Kavgac1, 2007; Kavgac1 et al., 2011; Direk, et al., 2012; Özkan and Kubaş, 2012).

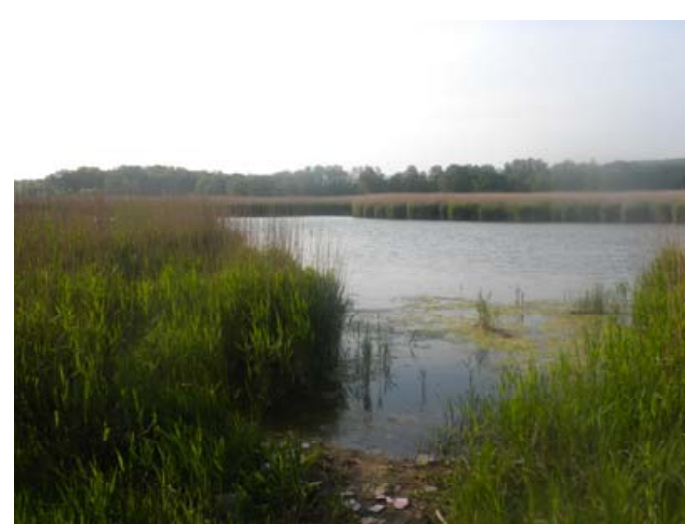

Fig 3. View of Lake Erikli and reed fields.

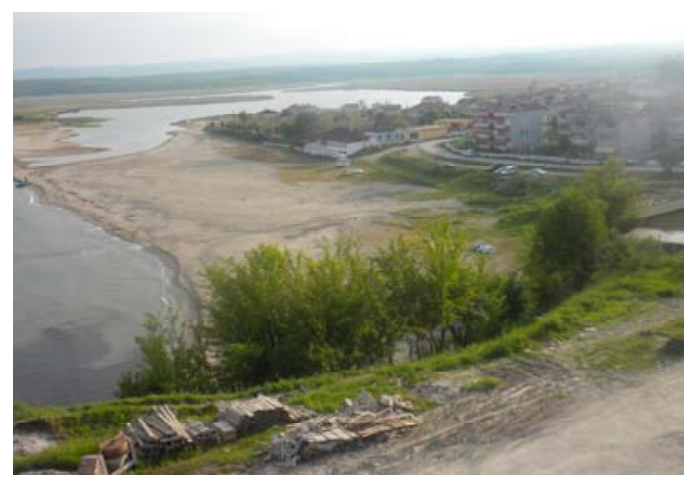

Fig 4. View of Lake Mert lagoon, south of İgneada, and summer homes. 
Tourism along coast between Lake Mert and Kıyık̈̈y

The longest beach between İğneada and Kıyıköy stretches along the shoreline to the south from Lake Mert lagoon. The so-called Panayır İskelesi beach is characterized by fine
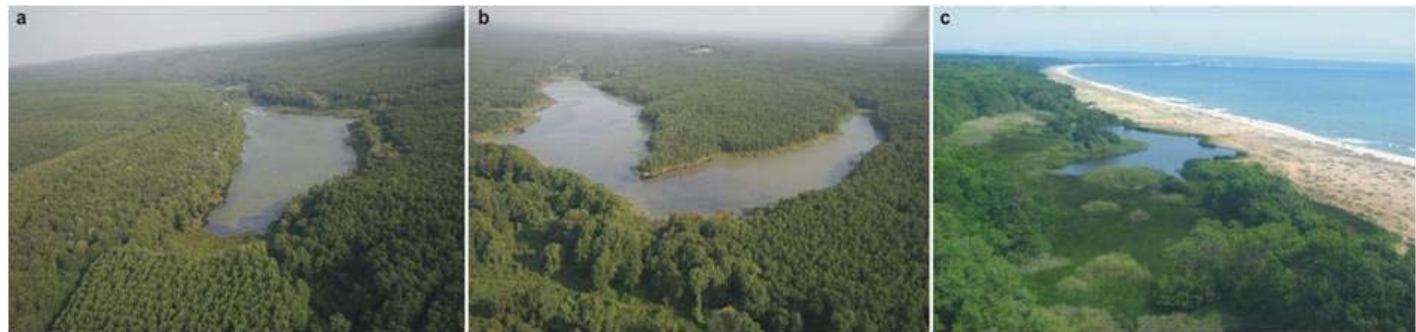

Fig 5. Lakes in lower basin of Bulanık Creek: (a) Lake Pedina, (b) Lake Hamam, and (c) Lake Saka. (Photo courtesy of Kıyıköy Municipality)
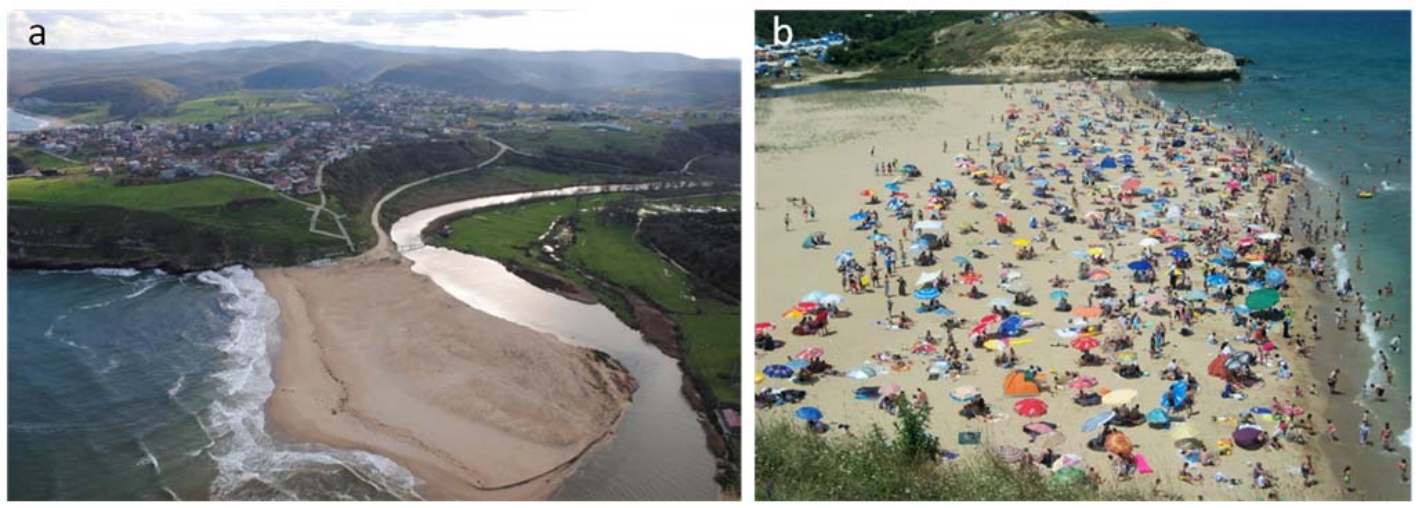

Fig 6. Views of Kıyıköy beach (a) before and (b) during tourism season (Photo courtesy of Kiyıöy Municipality).

In this area, there are some small lakes such as Lake Pedina (15 m asl), Lake Söğütlü (20 m asl), Lake Hamam (5 m asl), Lake Deniz (1 m asl) and Lake Saka (1 m asl) (Fig 5). The largest of these are the Hamam and Pedina lakes, surrounded by forest. Lakes Deniz and Saka, on the other hand, are found behind the shoreline.

This part of the coast between İğneada and Kıyıköy is important in terms of its attraction to tourists since it is a region where lagoons cover a wide area as well as forests of longose. However, it is reached only via an $8 \mathrm{~km}$-long stabilized road deviating south from the Demirköy-İğneada highway, which is not suitable for use until the end of May. Between June and August, the roads are convenient for sand and reaches a width of 90-120 $\mathrm{m}$ in general though it narrows to $30 \mathrm{~m}$ in places. It is estimated that this long sandy beach has an area of 131 hectares (Özkan and Kubaş, 2012). 
To the south of Lake Saka (north of Kiyiköy), another suitable area for tourism is Poliçe Bay. Also known as Poliçe Port, this bay is $700 \mathrm{~m}$ wide and consists of dirty white sand. About 1 meter behind the storm barrier extends a low sand dune ridge. Caravan-style accommodation exists on stabilized low sand dunes such as at Panayır İskelesi in the northern part of the bay. Selvez Beach, $250 \mathrm{~m}$ north of Kiyıköy, is a coastal strip preferred due to its proximity to the residential area. This beach, which has a length of more than $2 \mathrm{~km}$ and a width of $60 \mathrm{~m}$, is the most convenient and attractive beach in the vicinity of Kiyıköy. The beach is made up of light brownish and yellowish beach sand, and is limited to gullies that have developed on weathered granites. The beach is extremely clean and it was observed that local and foreign tourists set up tents on the beach. However, the northern part of the beach is mossy and the presence of seaweed (Posidonia) detracts from the quality of the beach.

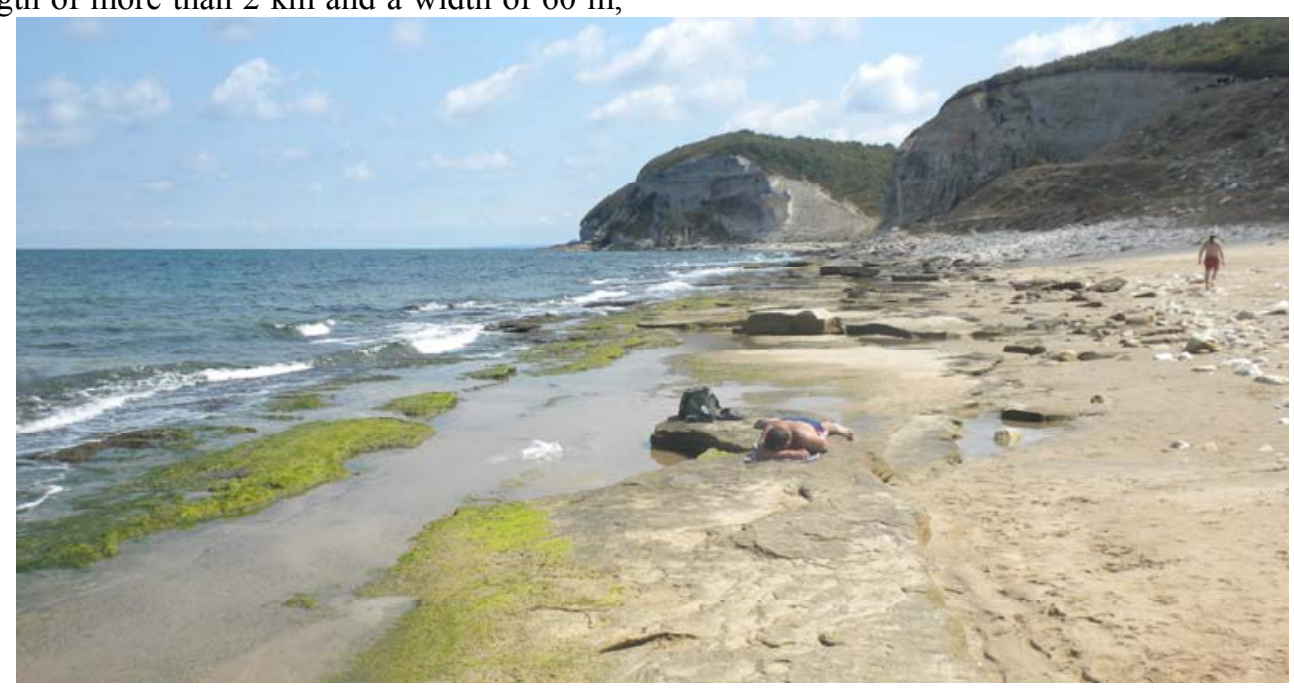

Fig 7. Beachrock used for sunbathing south of Kıyıköy Port.
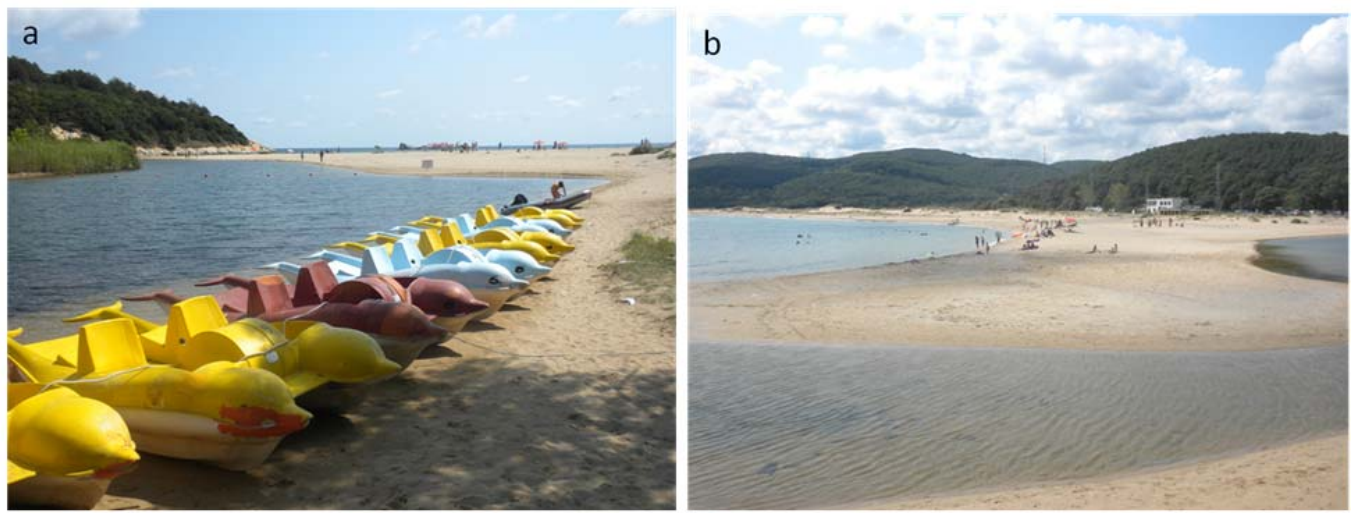

Fig 8. Views of Kastro Bay: (a) Sea biking and (b) coastal spit.

\section{Coastal tourism around Kıyıöy}

Geomorphologically, Kryık̈̈y and its environs comprise a low plateau dissected by three main creeks, i.e. the Pabuç, Kazan Dere and Elmalı creeks. Pabuç Creek discharges into the sea from the north of Kiyıköy. As the channel widens to $30 \mathrm{~m}$ at the mouth of the river, it provides a stretch $1.5 \mathrm{~km}$-long suitable for canoe tours. In this area, a large coastal spit exists with a length of $250 \mathrm{~m}$ and width of 140 $\mathrm{m}$ (Fig 6). This shoreline, providing an mportant opportunity for coastal tourism, is known as Kiyiköy Municipal Beach. 


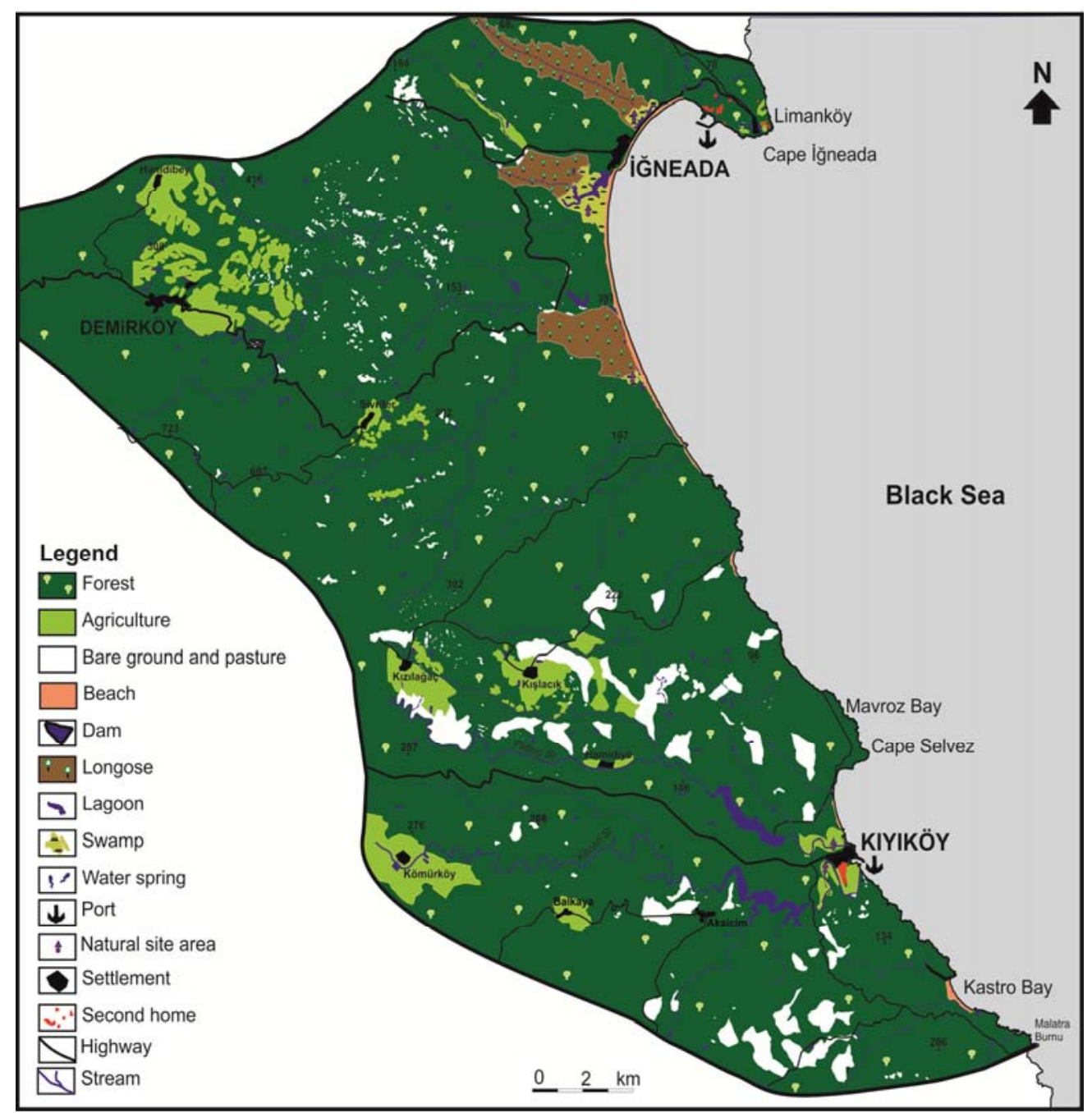

Fig 9. Land use map of the study area.

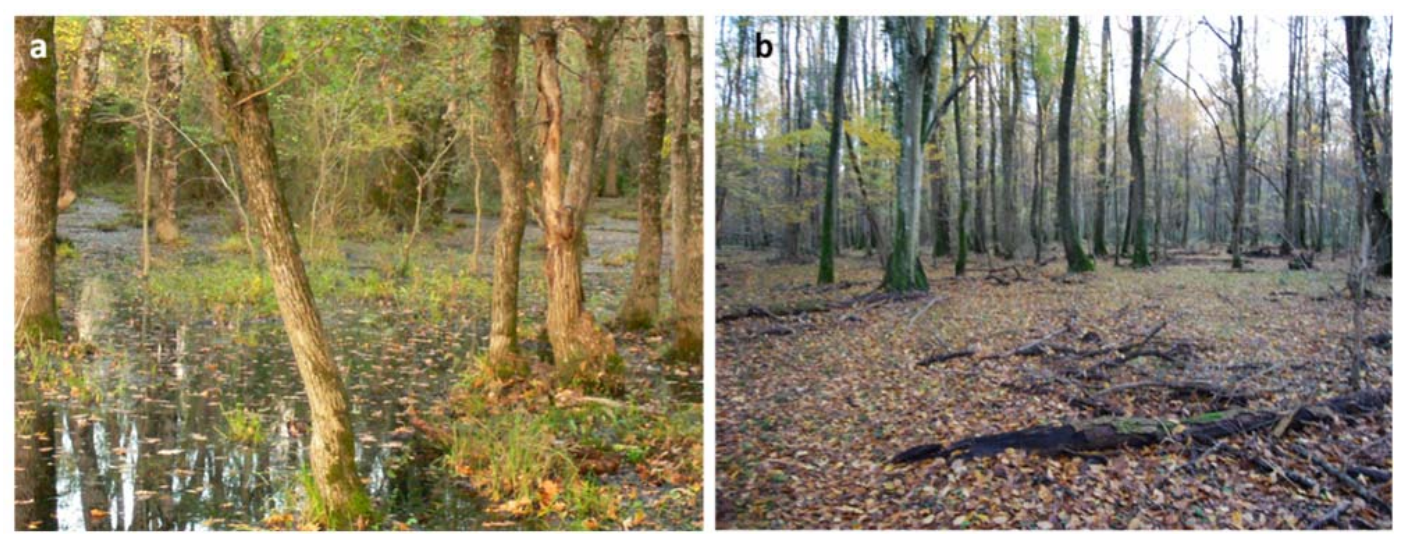

Fig 10. Longose forests around İğneada in (a) spring and (b) autumn (Photos: Orhan Uyanık) 
A 700-m-long beach extending southwards from another coastal spit south of Kiy1köy Port has developed in front of the coastal sand dunes, which are $3 \mathrm{~m}$ high. The beach ends at the southernmost part with beachrock beds in front of an old stone quarry (Fig 7). The beach is used extensively during the summer season, and the surface of the beachrock beds is popular for sunbathing. Even though such cemented beaches colonized by algae colonies are not preferred as they make access to the sea difficult, they are of great importance for controlling beach morphodynamics and coastal erosion (Kontogianni et al., 2014). Thus, beachrock beds, the unique outcrop from the Black Sea coast (Erginal et al., 2013) acts as a natural protective structure for the sandy beach.

\section{Coastal tourism around Kastro Bay}

Kastro Bay is a large bay with a length of 1.5 $\mathrm{km}$ in a northwest-southeastly direction and a maximum width of $450 \mathrm{~m}$ inland. Since the width of the stream bed behind Kastro Bay is 40 meters, this large bed allows for navigation by sea bikes for a distance of $1.5 \mathrm{~km}$ (Fig 8a). In this area, camping sites and picnic areas are common because reeds and forests cover a wide area. Kastro Bay is a favorite location in the summer months (Fig 8b). The average width of the beach is $100 \mathrm{~m}$. However, in the southern part of the bay, it is close to $200 \mathrm{~m}$. The beach slope is low and the beach is made up of dirty yellowish sand. Located $3 \mathrm{~km}$ south east of Kastro Bay, the inlets of Kefalagzı Bay and Korsan Bay offer unique scenes of outstanding beauty.

\section{Climatic comfort and coastal tourism}

According to the 32-year data from Kumköy Meteorology Station $\left(41.15^{\circ} \mathrm{N}-29.02^{\circ} \mathrm{D}\right)$ between 1975 and 2006, the average temperature in the study area is $13.8^{\circ} \mathrm{C}$. Taking the average values into account, there is an amplitude of $17.8^{\circ} \mathrm{C}$ within the year. With respect to average minimum and maximum values, on the other hand, the amplitude is $25^{\circ} \mathrm{C}$. In July and August, the average temperature is above $20^{\circ} \mathrm{C}$. This is true for the whole Black Sea coast and is the basic reason why the season in terms of coastal tourism is short. Starting from May, the total number of days when the maximum temperature is $20^{\circ} \mathrm{C}$ or higher during the day exceeds 10 . The maximum temperatures during the day near the end of June, July, August, and September are $20^{\circ} \mathrm{C}$ and above.

The maximum number of days when the temperature is $25^{\circ} \mathrm{C}$ or higher during the day exceeds 10 days in June-September. However, the number of days at $25^{\circ} \mathrm{C}$ and above is very small. Accordingly, the maximum temperatures during the day during summer are generally between $20^{\circ} \mathrm{C}$ and $25^{\circ} \mathrm{C}$. This corresponds to a comfortable period in terms of temperature for coastal tourism, which has a decisive influence on the increasing influx of visitors in JulyAugust.

Seawater temperatures, average air temperatures and insolation times run in parallel. The lowest values are in December on average for daily insolation duration, in February for average temperatures, and in March for seawater temperatures. The maximum insolation is reached in June, while the maximum average seawater temperatures occur in August. It is known that the optimum temperature in seawater varies between $22^{\circ} \mathrm{C}$ and $25^{\circ} \mathrm{C}$, and that temperatures below or above this are not preferred (Ülker, 1988). While these conditions are appropriate in July and August, they are not suitable for sea bathing overall since the seawater temperature is below $20^{\circ} \mathrm{C}$ before July and after August.

According to average cloudiness values, the days when cloudiness is between 0 and 1.9 can be considered as open days. Cloudiness on cloudy days ranges between 2 and 8 days. Regarding cloudy days which are not suitable for tourism, the number varies between 8.1 and 10 days. Thus, cloudiness has a negative effect on coastal tourism in the study area. In fact, this reduces the length of insolation and reduces the temperature of the air and seawater. With the exception of the months of July-August when sunbathing is relatively good, cloudiness leads to climatic discomfort in the study area.

Wind is represented as coming from different directions in every season. While SSW winds are generally dominant in winter, there are 
winds from every direction in the spring. The winds that are particularly effective during the summer period prevent the temperature from rising by having a cooling effect. This has a positive impact in terms of coastal tourism.

In this study, two climatic comfort indices were used to make a comparative analysis with selected tourism centers elsewhere in Turkey in order to evaluate the mentioned climatic characteristics in respect of tourism. Tables 1 and 2 show SSI values while Tables 3 and 4 show figures for THI. As is well-known, Climatic comfort studies consist of direct meteorological parameters expressed in simple mathematical formulas. Especially in tourism studies of Turkey, there has been an increase in research on this subject. Güçlü (2011) can be given as example. In the SSI index presented in Table 1 (also called the New Millennium Index), the air temperature and relative humidity values are taken as meteorological parameters (Tzenkova et al., 2007). Accordingly, SSI values are considered to be in the range of 70-150 and above. According to Kumköy Meteorological Station data, the area is suitable for coastal tourism from June to September.

Table 1. Monthly changes in SSI index values (1975-2006) at selected Turkish resorts.

\begin{tabular}{|c|c|c|c|c|c|c|c|c|c|c|c|c|}
\hline \multicolumn{13}{|c|}{ SSI $\left({ }^{\circ} \mathrm{C}\right)$ index values $(1975-2006)$} \\
\hline Station & Jan & Feb & Mar & Apr & May & Jun & Jul & Aug & Sept & Oct & Nov & Dec \\
\hline Kumköy & 30,75 & 29,98 & 35,14 & 47,28 & 61,33 & 76,43 & 84,47 & 85,40 & 73,95 & 61,63 & 7,21 & 37,19 \\
\hline Rize & 33,90 & 33,15 & 37,71 & 49,93 & 62,51 & 75,70 & 84,02 & 85,12 & 74,78 & 62,28 & 48,59 & 38,75 \\
\hline Zonguldak & 33,66 & 32,96 & 37,59 & 49,12 & 60,25 & 73,25 & 80,18 & 79,88 & 70,37 & 59,38 & 48,31 & 39,33 \\
\hline Florya & 31,57 & 30,51 & 36,49 & 50,03 & 63,90 & 78,14 & 85,48 & 85,37 & 74,84 & 62,15 & 47,72 & 37,45 \\
\hline Yalova & 34,20 & 34,20 & 39,24 & 52,10 & 65,51 & 79,28 & 86,09 & 85,97 & 74,97 & 62,23 & 48,65 & 39,97 \\
\hline Tekirdağ & 27,36 & 27,92 & 35,48 & 49,72 & 64,72 & 78,51 & 85,43 & 85,01 & 74,78 & 60,70 & 45,10 & 33,46 \\
\hline Ayvalık & 37,58 & 38,45 & 45,51 & 58,77 & 72,94 & 86,16 & 92,39 & 91,43 & 80,90 & 67,22 & 52,30 & 42,40 \\
\hline Bodrum & 48,79 & 48,58 & 53,93 & 63,20 & 75,55 & 87,00 & 93,28 & 93,30 & 84,70 & 74,28 & 61,57 & 52,70 \\
\hline Marmaris & 46,41 & 47,23 & 52,78 & 62,63 & 75,84 & 88,09 & 95,16 & 95,16 & 83,43 & 74,50 & 59,97 & 50,54 \\
\hline Fethiye & 39,50 & 46,94 & 52,66 & 62,51 & 74,74 & 86,59 & 93,79 & 93,74 & 83,92 & 71,20 & 57,29 & 48,41 \\
\hline Kaş & 52,52 & 52,03 & 55,99 & 64,69 & 75,97 & 85,84 & 93,56 & 94,63 & 87,05 & 76,25 & 64,81 & 56,25 \\
\hline Anamur & 48,52 & 48,65 & 54,53 & 64,94 & 77,36 & 89,63 & 98,58 & 98,27 & 89,00 & 76,71 & 62,87 & 53,05 \\
\hline Mersin & 46,50 & 48,25 & 56,10 & 67,82 & 79,56 & 91,07 & 99,63 & 100,32 & 91,13 & 78,17 & 61,53 & 50,63 \\
\hline
\end{tabular}

Table 2. Monthly THI (oC) index values (1975-2006) at selected Turkish resorts.

\begin{tabular}{|c|c|c|c|c|c|c|c|c|c|c|c|c|}
\hline \hline \multicolumn{10}{|c|}{ THI $^{\left.{ }^{\circ} \mathbf{C}\right)}$ index values (1975-2006) } \\
\hline Station & Jan & Feb & Mar & Apr & May & Jun & Jul & Aug & Sept & Oct & Nov & Dec \\
\hline Kumköy & 6,80 & 6,58 & 8,03 & 11,44 & 15,38 & 19,62 & 21,87 & 22,13 & 18,92 & 15,46 & 11,42 & 8,61 \\
\hline Rize & 7,68 & 7,47 & 8,75 & 12,18 & 15,71 & 19,41 & 21,75 & 22,05 & 19,15 & 15,64 & 11,80 & 9,05 \\
\hline Zonguldak & 7,62 & 7,42 & 8,72 & 11,96 & 15,08 & 18,73 & 20,67 & 20,59 & 17,92 & 14,83 & 11,73 & 9,21 \\
\hline Florya & 7,03 & 6,73 & 8,41 & 12,21 & 16,10 & 20,10 & 22,16 & 22,13 & 19,17 & 15,61 & 11,56 & 8,68 \\
\hline Yalova & 7,77 & 7,77 & 9,18 & 12,79 & 16,55 & 20,42 & 22,33 & 22,29 & 19,21 & 15,63 & 11,82 & 9,39 \\
\hline Tekirdağ & 5,85 & 6,00 & 8,13 & 12,12 & 16,33 & 20,20 & 22,14 & 22,02 & 19,15 & 15,20 & 10,82 & 7,56 \\
\hline Ayvalık & 8,72 & 8,96 & 10,94 & 14,66 & 18,64 & 22,35 & 24,10 & 23,83 & 20,87 & 17,03 & 12,85 & 10,07 \\
\hline Bodrum & 11,87 & 11,81 & 13,31 & 15,91 & 19,37 & 22,59 & 24,35 & 24,36 & 21,94 & 19,024 & 15,45 & 12,96 \\
\hline Marmaris & 11,20 & 11,43 & 12,98 & 15,75 & 19,45 & 22,89 & 24,88 & 24,88 & 22,45 & 19,08 & 15,00 & 12,35 \\
\hline Fethiye & 10,89 & 11,35 & 12,95 & 15,71 & 19,15 & 22,47 & 24,49 & 24,48 & 21,72 & 18,15 & 14,25 & 11,76 \\
\hline Kaş & 12,91 & 12,78 & 13,89 & 16,33 & 19,49 & 22,26 & 24,43 & 24,73 & 22,60 & 19,57 & 16,36 & 13,96 \\
\hline Anamur & 11,79 & 11,82 & 13,47 & 16,39 & 19,88 & 23,32 & 25,83 & 25,75 & 23,15 & 19,70 & 15,81 & 13,06 \\
\hline Mersin & 11,22 & 11,71 & 13,91 & 17,20 & 20,49 & 23,72 & 26,13 & 26,32 & 23,74 & 20,11 & 15,62 & 12,3862 \\
\hline
\end{tabular}

Thus, June and September are somewhat cool, but comfortable for most people. The July and August months are comfortable for everyone, but rather hot. Compared to the weather on the Mediterranean and Aegean coasts, however, full comfort is experienced for only two months. On the other hand, discomfort caused by a high increase in temperature is not the case with Black Sea resorts. In this location, the weather also creates more beneficial conditions in terms of health.

The THI index values are presented in Table 2 according to the Besansenot classification 
scheme (Tzenkova et al., 2007). In keeping with this, the May-June and September-October months are comfortable, while July and August are warm. The spread of the hot category especially over the Mediterranean coast for six months shows that sweltering warmth negatively affects comfort. In this case, the İgneada to Kastro Bay site THI values are comfortable for four months and in the warm category for two months.

\section{Potential of vegetation cover for tourism}

Based on the land use map generated from the CORINE land use classification produced by the Turkish Ministry of the Environment and Forestry, more than $80 \%$ of the study area is composed of forest land (Fig 9). The study area is located in the European-Siberian flora region, which completely covers the northern coasts of Turkey. Therefore, Euxine conditions are dominant in the area. In this context, plant cover in the study area can be evaluated in four groups, namely, moist (damp) forest, maquispseudomaquis, coastal plants, and longose forest.

The most remarkable plant community within this region is the damp forests (Atalay, 1994). Fagus orientalis and partly Rhododendron ponticum are common in the damp forests that ascend 500-600 $\mathrm{m}$ uphill on the northern slopes of the Yildiz Mountains. The rainfall in these forests usually exceeds $800 \mathrm{~mm}$. At higher elevations, the precipitation can reach up to $1400 \mathrm{~mm}$. In the coastal region, these forests descend to the pseudo-maquis and cover a limited area.

In the damp forests covering the northern part of the Yildız Mountains, the common characteristic species of the Euxine zone are Acer campestre, Alnus glutinosa, Carpinus betulus, Carpinus orientalis, Corylus avellana, Fagus orientalis, Rhododendron ponticum, Mespilus germanica, Quercus petraea, Quercus hartwissiana, Quercus robur and Sorbus torminalis (Dönmez, 1968). Fagus orientalis dominates among the tree species mentioned. Another important feature of these forests is that they have a rich undergrowth flora represented by Rhododendron ponticum and Ilex aquifolium (Dönmez, 1968). Although Fagus orientalis predominates, Fagus sylvatica was also found, especially between the town of İğneada and village of Sislioba (Aydınözü, 2010). Quercus petraea is commonly found at levels between 500 and 600 meters above sea level. Towards the shore, oak forests cover the fields as a result of the destruction of beech trees (Dönmez, 1968). At altitudes less than 300 meters, oak is the dominant species.

In the forests of Fagus orientalis, undergrowth communities composed of Rhododendron ponticum and Ilex aquifolium have broad distribution. In addition, Daphne pontica, Euphorbia amygdaloides, Hypericum sp., Trifolium sp., Rubus fruticosus, Fragaria vesca, Cistus villosus, Luzula sp., Viola silvatica, Campanula sp., Ranunculus primula, Genista tinctoria and pteridophytes etc. form dense communities.

In the study area, there are maquis and pseudomaquis communities along the shoreline from Kastro Bay to Iğneada. These plant communities, observed at up to $100 \mathrm{~m}$ elevation near Kastro Bay, are seen at between 30-40 m above sea level in the vicinity of İgneada. In this area, species of Phillyrea latifolia, Arbutus unedo, Pistacia terebinthus and Cistus salviifolius have developed. Pseudo-maquis along the coast of Limanköy consists of species such as Phillyrea latifolia, Pistacia terebinthus, Paliurus aculeatus, Asparagus officinalis, Carpinus sp., Fraxinus ornus and Cornus mas.

Coastal plants consisting of salt-tolerant species are mostly observed on low sand dunes, especially behind sandy beaches, and are found around Iğneada, Kıyıköy and Kastro Bay. The main species are Ammophila arenaria, Anthemis maritima sp., Centaurea sp., Convolvulus sp., Euphorbia sp. Ganucium flavum, Pancratium maritimum, Salicornia sp., Silene sp. and Verbascum sp.

Alluvial plains at the mouth of rivers are home to longose (subasar) forests in the rainy season. These forests have developed extensively on the moist soil and clayey soils (Fig 10). Longose is an ecosystem formed by the accumulation of sand brought down by streams flowing into the sea, creating a barrier on the shore that closes the mouth of the stream. The most important condition for the sustainability 
of this unique ecosystem is abundance of water, transporting the clay and organic material onto the soil and thereby enriching it in mineral and organic material. Only certain types of trees and plants (e.g. Leucojum aestium, Butomus umbellatus, etc.) and bird species (e.g. Ciconia nigra) have adapted to this habitat.

The main plant elements of the longose forest in the study area are Fraxinus ornus, Alnus glutinosa, Ulmus campestris and Salix sp., with proportions of $50 \%, 34 \%, 11 \%$ and $5 \%$, respectively (Atalay, 1994). Acer campestre, Populus tremula, Carpinus orientalis, Fagus orientalis and some oak species are observed in lesser quantities. Species such as Prunus spinosa, Rubus fruticosa, Corylus avellana, Acer pseudoplatanus, Crataegus monogyna, Sorbus torminalis, Sambucus nigra, Hedera helix and Similax excelsa form the shrub level of the longose forest. Rubernus fruticosus, Ranunculus sp., Veronica hederifolia, and Viola silvatica constitute the undergrowth ecosystem of the forest.

These longose forests are registered as a National Park and cover an area of 3,000 hectares (Özyavuz and Yazgan, 2010). They are found in remarkable abundance on the alluvial plains of Çavusdere and Bulanıkdere streams to the south of İgneada town. In the downstream of Rezvadere to the north of İgneada, another longose forest comprises a narrow corridor extending $1 \mathrm{~km}$ inland from the coast. Some of the moist alluvial plains around İğneada are covered with Fraxinus ornus communities.

The best example is the large alluvial plain of the Efendi Stream behind Lake Erikli north of Iğneada. This valley basin is covered with Fraxinus associations. Along with this, some communities of Corylus, Ulmus, Populus, Carpinus and Quercus are found. Another important distribution area of the Fraxinus species is located to the north-east of Lake Erikli.

\section{Ecotourism potential based on floristic variety}

The study area has great potential for ecotourism due to its rich flora, such as the damp forests, shrubs and pseudomassic communities, salt plants on sand dunes and longose forests. The forests are preferred by visitors for their clean air and suitable climatic comfort conditions in the months when the temperature is higher. Many activities are possible in the forest, such as picnicking, trekking, camping and photography. Forest flora and fauna richness play a major role as well as the presence of clean water sources suitable for angling in the forest. To exploit this potential, there is a need to invest in tourism facilities which may include rest places in the forest, watchtowers, and bird and wildlife observation hides. The Hamam and Pedina lakes in the forest and the lagoons on the coast offer extremely favorable conditions for nature photography and trekking. There are several walking routes, such as the İgneada-Lake Mert-Sivriler route along the coast, the Lake Saka route along Bulanık Creek valley, the İğneada-Lake Mert route and the DemirköyKadınkule-Monapetra-Velika Bridge route in the inner part. However, there is a need to signpost the walkways along these routes (Çakır and Çakır, 2012). Lake Mert and its vicinity near İğneada, which is at the entrance to İgneada and Lake Erikli, is one of the favorite picnic areas. Except for the high quality asphalt roads between İgneadaDemirköy and Vize-Kiyıköy, the roads through the forested areas are almost completely dirt roads. This should not be regarded as a deficiency since guided walks and group safari tours can be organized along these tracks. These forest roads are also suitable for cycling events and trekking.

\section{Conclusion}

The coastal area between İğneada and Kastro Bay to the south of Kiyıköy is characterized by various geomorphological units such as lowlying plateau surfaces dissected by river valleys within damp forests, sandy beaches, coastal spits and sheltered bays. These provide various opportunities for coastal tourism and alternative tourism activities. Unfortunately, tourism in the area has made little progress so far. This is mainly due to the shortness of the summer season for coastal tourism. As confirmed by the Summer Simmer and Thermo-Hygrometric indices, July and August are the most comfortable in terms of traditional sun, sea and sand tourism. Due to warm but lower air temperatures compared to the Mediterranean coast, this provides favorable conditions for the health of visitors as well. The asset of damp forests as well as longose in the area, together with streams that lead to wide-mouthed estuaries, may be a boon for ecotourism and other tourism activities. Despite the enormous ecotourism potential of the area, tourism is limited to coastal tourism from June to August. Since camping is the most common and 
preferred type of accommodation, the lakes, stream valleys and beaches face serious environmental problems if growth continues unabated. Therefore, all these factors need to be taken into consideration when planning a sustainable tourism agenda for this region.

\section{Acknowledgements}

This paper was prepared from the author's MA dissertation. Prof. Okan Yasar is thanked for his enormous contribution as academic advisor and Mr. G. H. Lee for checking the English.

\section{References}

Akkaya, M., Gazioğlu, C., Yücel, Z. Y., Burak, S. (1998). "Kıyı Alanlarının Rasyonel Kullanımı ve Yönetiminde Kamu Yararı İlkesi”, Türkiye Kıyıları 98, (Ed: Özhan, E.), METU, Ankara: 39-47, 22-25 September 1998.

Atalay, İ. (1994). Türkiye Vejetasyon Coğrafyası. Ege Üni. Basımevi, $352 \mathrm{~s}$, Bornova/İzmir.

Atik, M., Altan, T., Artar, M. (2010). Land Use Changes in Relation to Coastal Tourism Developments in Turkish Mediterranean, Polish Journal of Environmental Studies, 19(1), 21-33.

Aydınözü, D. (2010). Avrupa Kayını (Fagus sylvatica)'nın Yıldız (Istranca) dağlarındaki Yeni Yayılış Alanları, K.Ü. Kastamonu Eğitim Dergisi, 18(2), 623-630.

Burak, S., Doğan, E. and Gazioğlu, C. (2004). Impact of urbanization and tourism on coastal environment. Ocean and Coastal Management, 47, 515-527.

Çakır, G., Çakır, A. (2012). İğneada Longoz Ormanları ve Çevresinin Rekreasyonel Faaliyetler Açısından Değerlendirilmesi, KSÜ Doğa Bilimleri Dergisi, Özel Sayı, 281-286.

Demir, S., Esbah, H., Akgün, A.A. (2016). Quantitative SWOT analysis for prioritizing ecotourism-planning decisions in protected areas: Igneada case, International Journal of Sustainable Development \& World Ecology, 23(5), 456-468.

Dihkan, M., Güneroğlu, N., Güneroğlu, A. and Karsl1, F. (2017). The need for ecosystembased coastal planning in Trabzon city, International Journal of Environment and
Geoinformatics (IJEGEO), Vol.4(3): 193205.

Direk, Ş., Şeker, DZ., Musaoğlu, N and Gazioğlu, C. (2012). Monitoring and Management of Coastal Zones Which are Under Flooding Risk with Remote Sensing and GIS, AGU, Fall Meeting 2012. 1596.

Dönmez, Y. (1968). Trakya'nın Bitki Coğrafyası. Taş Matbaası, $279 \mathrm{~s}$.

Erginal, A.E., Ekinci, Y.L., Demirci, A., Bozcu, M., Ozturk, M.Z., Avcioglu, M., Oztura, M.Z. (2013). First record of beachrock on Black Sea coast of Turkey: Implications for Late Holocene sea-level fluctuations, Sedimentary Geology, 294, 294-302.

Gazioğlu C, Yücel Y Z, Burak S., Okuş, E. and Alpar, B. (1997). Coastline change and inadequate management between Kilyos and Karaburun shoreline. Turkish Journal of Marine Sciences, 3(2): 111-122.

Gazioğlu, C., Akkaya, M.A., Baltaoğlu, S. and Burrak, S.Z. (2016). ICZM and the Sea of Marmara: The İstanbul Case. The Sea of Marmara: Marine Biodiversity, Fisheries, Conservations and Governance (Editors: Özsoy, E., Çağatay, M.N., Balkıs, N., Balkıs Çağlar, N., Öztürk, B.): 935-957.

Güclü, Y. (2011). The determination of sea tourism season with respect to climatical conditions on the black sea region of Turkey. 2nd International Geography Symposium-Mediterranean Environment 2010 ,Vol. 19, pp. 258-269, DOI: 10.1016/j.sbspro.2011.05.131.

Iyigun, C., Türkeş, M., Batmaz, İ., Yozgatligil, C., Purutçuoğlu, V., Koç, E.K., Öztürk, M.Z. (2013). Clustering current climate regions of Turkey by using a multivariate statistical method, Theoretical and Applied Climatology, 114, 95-106.

Kavgac1, A. (2007). Demirköy-İğneada Longos Ormanları ve Çevresinin Bitki Toplumları ve Kuruluş Özellikleri. İ.Ü. Fen Bilimleri Enstitüsü Orman Mühendisliği ABD, Doktora tezi.

Kavgac1, A., Čarni A., Tecimen, B., Özalp, G. (2011). Diversity of floodplain forests in the Igneada region (NW Thrace-Turkey), Hacquetia, 10(1), 73-93.

Kontogianni, A., Damigos, D., Tourkolias, Ch., Vousdoukas, M., Velegrakis, A., Zanou, B., Skourtos, M. (2014). Eliciting beach users' 
willingness to pay for protecting European beaches from beachrock processes, Ocean \& Coastal Management, 98, 167-175.

Kuleli, T. (2010). City based risk assessment of sea level rise using topographic and census data for Turkish coastal zone. Estuaries and Coasts, Journal of the Estuarine Research Federation, 33, 640-651.

Kurter, A. (1964). Limanköy Platosu ve İğneada Neojen havzasının morfolojisi, İ.Ü. Coğrafya Enstitüsü Dergisi, 8(14), 132- 148.

Kuvan, Y. (2012). Assessing the impacts of tourism on forests: Mass tourism and policy in Turkey, Environmental Engineering and Management Journal, 11(8), 1415-1424.

Malkoçlu, K., Anıl, N.K., Bilgen, E. (2011). Destinasyon Markalaşmasi: Vize'nin Turizm Destinasyonu Olarak Pazarlanmas1 ve Markalaşması. Uluslararası II. Trakya Bölgesi Kalkınma - Girişimcilik Sempozyumu Bildiri Kitabı I, 231-245.

Morgül, Ş. (2014). Kirklareli İlinde Eko Turizm Olanaklari, Electronic Journal of Vocational Colleges, 27-38. http://www.ejovoc.org/makaleler/aralik_201 4/pdf/03.pdf.

Özkan, E., Kubaş, A. (2012). Yıldız Dağlarında Kırsal Kalkınmada Ekoturizm Firsatları, KMÜ Sosyal ve Ekonomik Araştırmalar Dergisi, 14(22), 149-153.

Özyavuz, M. (2008). Yıldız Dağları'nın iğneada - Demirköy Arasında Yer Alan Bölümünün biyosfer Rezervi Olarak Planlanmas1, Ankara Üniversitesi Fen Bilimleri Enstitüsü, Doktora Tezi, Ankara.

Özyavuz, M. (2011). Determination of temporal changes in lakes Mert and Erikli using remote sensing and geographic information systems, Journal of Coastal Research, 27(1), 174-181.

Özyavuz, M., Yazgan, M.E. (2010). Planning of Igneada Longos (Flooded) Forests as a Biosphere Reserve, Journal of Coastal Research, 26, 1104-1111.

Pamir, HN., Baykal, F. (1947). The geological structure of the Strandja Massif, Bulletin of the Geological Society of Turkey, 1, 7-43.

Pepi, J.W. (1999). The New Summer Simmer Index - A Comfort Index For The New Millennium, (http:// www. Summersimmer .com).

Şenlier, N., Öztürk, G. (2011). Investigation of Fragility to Estimate Tourism Pressure,
Journal of Coastal Research, Special Issue 61 - Management of Recreational Resources, pp. $217-220$.

Simav, Ç., Seker, D.Z., Tanık, A., Gazioğlu, C. (2015). Determining the endangered fields of Turkish coasts with coastal vulnerability index. TMMOB Congress, 11-13 November 2015, Ankara, Turkey.

Şeker, D.Z., Tanık, A., Çitil, E., Öztürk, İ., Övez S. and Baycan, T. (2016). Importance and Vulnerability Analyses for Functional Zoning in a Coastal District of Turkey, International Journal of Environment and Geoinformatics Vol.3(3):76-91.

Türkeş, M. (1996). Spatial and temporal analysis of annual rainfall variations in Turkey, International Journal of Climatology. 16, 1057-1076.

Tzenkova, A., Ivancheva, J., Koleva, E., Videnov, P. (2007). The human confort conditions at Bulgarian Black Sea side, Andreas Matzarakis, Christopher de Freitas ve Daniel Scott (eds). Developments in Tourism Climatology, 150-157.

Ülker, İ. (1988). Türkiye'de Sağlık Turizmi ve Kaplıca Planlaması, Kültür ve Turizm Bakanlığı Yayını, Ankara.

Yilmaz, O., Mansuroglu, S., Yilmaz, R. (2013). Swot analysis of ecotourism as a tool for sustainable development: a case research in north-west Black Sea coastal zone of Turkey, Journal of Environmental Protection and Ecology, 14(2), 786-798. 